\title{
Retrospekcja o genezie i trwałości powojennych polichromii kamienic Starego Rynku w Poznaniu
}

\author{
Andrzej Maciej Łubowski \\ https://orcid.org/0000-0002-5034-857X \\ andrzej.lubowski@put.poznan.pl \\ Instytut Architektury Wnętrz i Wzornictwa Przemysłowego, \\ Wydziat Architektury, Politechnika Poznańska
}

\begin{abstract}
Streszczenie: Artykuł prezentuje autorskie doświadczenia twórcze artysty i jednocześnie badacza, związane z wykonaniem dekoracji malarskiej kamienic na Starym Rynku, w Poznaniu. Są to dzieła powstałe w latach: 1986, 1994 oraz 1997.

Pierwsza realizacja była konsekwencją dość niespodziewanego włączenia w dzieło powstawania polichromii kamienic na Starym Rynku, w Poznaniu. Było to, po około 30 latach po powstaniu polichromii na zrekonstruowanych kamieniczkach, po II Wojnie Światowej. Zaistniała potrzeba odtworzenia dekoracji malarskiej autorstwa Edmunda Łubowskiego, na kamienicy na Starym Rynku 39 oraz sgraffita ${ }^{1}$, autorstwa Józefa Fliegera, na Starym Rynku 99. Sytuacja była konsekwencją tak dalekiej destrukcji, że nie można było poddać tych dzieł odnowieniu. Z uwagi, iż autorzy jeszcze wtedy żyli, możliwe było konsultowanie przebiegu ich odtworzenia.

W 1994 roku autor otrzymał kolejną propozycję wykonania, według autorskiego projektu, nowej dekoracji malarskiej na kamienicy na Starym Rynku 66, która została wykonana w technice mokrego fresku². Później, w 2010 r. została przeprowadzona konserwacja i restauracja tego dzieła, przebieg prac odbywał się w konsultacji z autorem.

W 1997 zaprojektowano dekorację malarską na kamienicy przy ul. Paderewskiego 3, blisko wnętrza urbanistycznego Starego Rynku. W oparciu o projekt, wykonano malarską dekorację w technice silikatowej ${ }^{3}$.

Doświadczenie artysty, wyniesione z tych wymienionych prac, stały się przedmiotem badań jakościowych, które korelują ze sobą upływ czasu i rodzaj stosowanych technik malarstwa ściennego oraz innych uwarunkowań technicznych wpływających na stan zachowania polichromii z problematyką artystyczną.
\end{abstract}

Słowa kluczowe: architektura, odbudowa, polichromia, Stary Rynek w Poznaniu, spoiwa mineralne, stan zachowania, konserwacja, restauracja

\section{Syntetyczny rys historyczny}

Poznań to jedno z najstarszych miast Polski, do lat 40. XIII wieku istniał na prawym brzegu Warty, jako potężny gród Ostrów Tumski wraz osadą targową Śródką ${ }^{4}$.

W XIII wieku zaistniała potrzeba stworzenia miasta spełniającego wymogi ówczesnych czasów i nastąpiły przygotowania do jego lokacji na lewym brzegu Warty, gdzie istniały trzy osady: Św. Gotarda, Św. Marcina

1 K. Zwolińska, Sgraffito, w: Mała technologia malarstwa, Wydawnictwo Centralnego Ośrodka Metodyki Upowszechniania Kultury, Warszawa 1989, s. 168

2 Ibidem, Fresk s. 149

3 P. Przybek, Farby silikatowe, w: Materiaty Malarskie, Wydawnictwo 400 d\&, Kraków 2004, s. 23.

4 A. Rogalanka, Poznań u progu lokacji. Na prawym brzegu Warty, rozdz. VII, Lokacja miasta na lewym brzegu Warty w 1253 roku, w: Jerzy Topolski (red), Dzieje Poznania, tom I, PWN, Warszawa-Poznań 1988, s. 146-150. 
i Św. Wojciecha. Książę Przemysł I w roku 1244, po zamianie z biskupem osady Św. Wojciecha, na osadę Św. Gotarda, przeniósł siedzibę zakonu dominikanów, ze Śródki na teren osady Św. Gotarda, na lewym brzegu Warty ${ }^{5}$.

W 1253 roku na terenie osady ukończono budowę wczesnogotyckiego kościoła należącego do zakonu dominikanów. Także w 1253 roku powstał dokument lokacyjny, z inicjatywy braci: książąt Przemysła I oraz Bolesława Pobożnego, zlecający Tomaszowi z Gubina osadzenie miasta na prawie magdeburskim ${ }^{6}$

Miasto posiadało centralny rynek, w kształcie zbliżonym do kwadratu o boku około $140 \mathrm{~m}$, z układem odchodzących od niego 12 ulic, po 3 na każdą pierzeję z głównymi, wylotowymi ulicami wychodzącymi ze środka pierzei północnej i południowej, tworzącymi główną oś założenia miasta. Wokół rynku, na ośmiu blokach, zostały wytyczone parcele mieszkalne ${ }^{7}$.

Początkowo działki były zabudowywane obiektami drewnianymi, dopiero od schyłku XV wieku drewniana zabudowa była zastępowana obiektami murowanymi ${ }^{8}$.

W lutym 1945 roku został zniszczony, na skutek działań wojennych, w 60\% Stary Rynek i jego najbliższe otoczenie. Zbigniew Zieliński, architekt, kierownik Wydziału Planowania i Rozbudowy Miasta w lipcu 1946 roku przedstawił plan zabudowy zabytkowego centrum, a 1947 roku opracował pierwsze rysunki rekonstrukcji elewacji. Rekonstrukcje odwoływały się XVIII wieku czyli do czasów przedrozbiorowych. W 1954 roku powstał jednorodny, pozbawiony nawarstwień historycznych projekt pierzei rynkowych ${ }^{9}$.

Przygotowano kompleksową dokumentację architektoniczną oraz w końcu 1954 roku zajęto się kolorystycznym opracowaniem elewacji, traktując wnętrze urbanistyczne Starego Rynku, jako zharmonizowaną całość. W przeciwieństwie do przekazów ikonograficznych o architekturze kamienic na Starym Rynku w Poznaniu przekazy o polichromii istniejącej w przeszłości były skąpe lub w wielu przypadkach nie było ich wcale. W związku z powyższym podjęto się nowego twórczego poszukiwania. W wyniku konkursu ostatecznie na początku 1955 roku przyjęto projekt artysty plastyka Zbigniewa Bednarowicza, który został generalnym projektantem i koordynatorem prac plastycznych. Szczegółowe projekty polichromii wykonywane były przez zespoły i poszczególnych artystów plastyków, W pracach uczestniczyli artyści plastycy głównie ze środowiska poznańskiego ${ }^{10}$

\section{Dekoracja malarska kamienicy na Starym Rynku 66}

Propozycja wykonania nowej dekoracji malarskiej na elewacji kamienicy na Starym Rynku 66 w Poznaniu pojawiła się w 1994 roku. Nie bez znaczenia dla wyboru artysty był fakt jego doświadczeń z młodych lat i możliwość obserwacji odbudowy Starego Rynku, w tym uczestnictwo w niej, w zakresie wystroju plastycznego Edmunda Łubowskiego ${ }^{11}$, stąd pierwsza fascynacja powstawaniem polichromii budynków tam odbudowywanych. Istotna była również bliskość środowiska artystów plastyków uczestniczących w tym dziele, które było w tamtych latach o wiele bardziej zintegrowane niż obecnie.

Nie sposób nie docenić ówczesnego wysiłku osób zaangażowanych w odbudowę Starego Rynku, mimo panujących wtedy uwarunkowań gospodarczych, ustrojowych i ideologicznych, był to heroiczny wysiłek zwieńczony satysfakcjonującym rezultatem.

Istotny jest wiek artysty, w szczególności moment, kiedy historyczna przeszłość staje się ważna i będącego w trakcie realizacji jego zainteresowań historią i zabytkami Poznania oraz całej Polski, jak to miało miejsce przy tworzeniu przez niego nowej polichromii.

5 Ibidem, Na lewym brzegu Warty, s. 163-166.

6 Z. Kaczmarczyk, Ustrój miasta lokacyjnego, rozdz. VII, Lokacja miasta na lewym brzegu Warty w 1253 roku, w: Jerzy Topolski (red), Dzieje Poznania, tom I, PWN, Warszawa-Poznań 1988, s. 186.

7 P. Wawrzyniak, Najdawniejsze dzieje Starego Rynku. Próba podsumowania badań archeologicznych, w: W cieniu ratuszowej wieży, Kronika Miasta Poznania, 2003/2, Poznań 2003, s. 7.

8 A. Gąsiorowski, Późnośredniowieczna konurbacja poznańska, rozdz. VIII, Miasto późnośredniowieczne, w: Jerzy Topolski (red), Dzieje Poznania tom I, PWN, Warszawa-Poznań 1988, s. 223-224.

9 G. Klause, Próba nowego spojrzenia na problem odbudowy Starego Rynku, w: W cieniu ratuszowej wieży, Kronika Miasta Poznania, 2003/2, Poznań s. 450-451.

10 H. Kondziela, Konserwatorstwo, w: T. Kostyrko (red), Sztuki plastyczne w Poznaniu, Wydawnictwo Poznańskie, Poznań 1987, s. 161.

11 Edmund Łubowski - artysta plastyk, ojciec Pawła i Andrzeja Macieja Łubowskich. 
Kamienica na Starym Rynku 66 ma XV wieczny rodowód, była kilkakrotnie przebudowywana, w pierwszej połowie XVIII wieku, następnie w drugiej połowie XIX wieku i podwyższona o jedno piętro, w 1945 roku została zniszczona. W 1956 roku odbudowano ją od parteru na średniowiecznej działce. Projekt budynku wykonała Janina Czarnecka. Fasada została pokryta polichromią wykonaną przez zespół artystów plastyków w składzie: Bartłomiej Kurka, Andrzej Matuszewski i Irena Psarska.

Po wykonaniu prac blacharsko - dekarskich i elewacyjnych w 1982 roku Andrzej Matuszewski zaprojektował dekorację malarską, która została wykonana w technice akrylowej ${ }^{12}$.

Wykonawstwo w 1994 było realizowane wg wcześniejszego projektu z 1988 roku. Prawdopodobnie z powodu tego, że stan zachowania poprzedniej realizacji z 1982 roku był zły, choć być może były jeszcze jakieś inne uwarunkowania.

Na kamienicy przy Starym Rynku 66 były wcześniejsze powojenne polichromie, lecz Biuro Miejskiego Konserwatora Zabytków zaleciło zaprojektowanie zupełnie nowej dekoracji malarskiej, bez sugerowania się poprzednimi projektami. Autor otrzymał w 1994 roku pozwolenie na projektowanie i wykonawstwo malarstwa ściennego w obiektach zabytkowych. ${ }^{13}$

Główny projektant polichromii Starego Rynku Zbigniew Bednarowicz, ustalił kolorystykę elewacji i technikę wykonania dekoracji malarskiej, zaproponował mokry fresk.

Projekty polichromii kamienic w czasach odbudowy Starego Rynku w swej estetyce nawiązywały, do współczesnych autorom, tendencji w plastyce, takie było założenie. Trzeba przyznać, że pomimo, iż na początku odbudowy panowała doktryna socrealizmu, to w polichromiach kamienic Starego Rynku tego nie widać.

Od momentu zaprojektowania polichromii elewacji kamienicy już w 1988 roku, w sztukach plastycznych pojawiły się inne tendencje, natomiast od procesu odbudowy Starego Rynku minęło około 30 lat. Wiadomo, że wiek XX był burzliwy w kwestii powstawania i zmian tendencji w sztuce. W sztukach plastycznych, 1988 rok, w którym powstał projekt był już zupełnie innym czasem, wielka narracja awangardowa załamała się, kryterium nowości przestało obowiązywać, artyści zaczęli odważnie sięgać do stylistyk przeszłości, cytując je w swoich dziełach. Stąd właśnie zainteresowania historią, skłoniło autora do sięgnięcia do ikonografii arrasów wawelskich, nadającej się do przełożenia na inne medium, jakim jest malarstwo ścienne (ryc. 5). Był jeszcze jeden powód sięgnięcia do arrasów wawelskich, były one wyposażeniem Wawelu, siedziby królewskiej, a przecież Poznań był miastem królewskim i związki Poznania ze stolicą Polski, Krakowem były przez kilka wieków rozkwitu Polski bardzo istotne.

Kolor elewacji był ustalony przez Zbigniewa Bednarowicza, była to stonowana, zimna zieleń, obramienia okienne były kremowe, dużo jaśniejsze. Dążono do tego, by rozmieścić elementy kompozycji tak, jak w tkaninach ozdobnych np. dywanach równomiernie po całej powierzchni malatury, od końca parteru do szczytu kamienicy. Między oknami pierwszego i drugiego piętra wydzielono poziomy pas lekko jaśniejszy, ograniczony dwoma białymi liniami, pozwalający ustosunkować się do architektury, z fantazyjnymi postaciami zaczerpniętymi z ikonografii arrasów ze skrzydłami i zawiniętymi, przypominającymi rybie, ogonami i trzymającymi w rękach niebieskie wazy. Dwa pionowe pasy umieszczono także na szczycie fasady. Resztę powierzchni oplata wić roślinna, ugrowa winorośl z niebieskimi gronami, dodano również kilka stylizowanych czerwonych kwiatów. Jeżeli chodzi o kolory przeważa ugier, postacie są malowane sieną paloną, modelowane z przewagą ciemnych płaszczyzn, aby wyłaniały się z powierzchni malowidła, to samo dotyczy ugrowych liści winogron, są różnicowane w walorze w tym samym celu i kontrastują z zielonkawym tłem. Nad oknem, na szczycie elewacji umieszczono stylizowaną, podpiętą z dwóch stron, kotarę w kolorze jasnego ugru.

Polichromię wykonano w technice mokrego fresku, malując na niewielkich powierzchniach barwionej, mokrej zaprawy, nakładanej sukcesywnie przez tynkarza. Istotne było zwracanie nieustanne uwagi, żeby zaprawa nie była zbyt sucha, bo mogłaby się nie związać z pigmentami rozprowadzonymi wodą wapienną, jako rozcieńczalnikiem. W prawidłowo wykonanym fresku kolorowe pigmenty wiążą się na stałe z tynkiem, zawierającym gaszone wapno. Trudnością jest także to, że tynk jaśnieje po wyschnięciu, trzeba więc mieć wyczucie, żeby nie przebielić malatury. Ta stara technika jest bardzo szlachetna i można w niej dość elastycznie operować środkami.

12 H. Kondziela, Stary Rynek, Kamienica 66, Sprawozdania konserwatorskie z prac w latach 1945-2016, część 2, w: I. Błaszczyk (red), Stare Miasto w Poznaniu. Zniszczenia Odbudowa Konserwacja 1945-2016, Wydawnictwo Miejskie Posnania, Poznań 2017, s. 206.

13 Zaświadczenie nr 22/94 Wojewódzkiego Konserwatora Zabytków w Poznaniu o posiadaniu kwalifikacji w zakresie projektowania i realizacji malarstwa ściennego w obiektach zabytkowych. 
Dekorację malarską wykonywano na tradycyjnych, drewnianych, rusztowaniach tak, jak to robili artyści plastycy po wojnie, w czasie odbudowy Starego Rynku.

Po 16 latach, w 2010 roku odnowiona została fasada z wystrojem malarskim. Wystrój malarski został poddany udanej konserwacji i restauracji (ryc. 1 i 2). Obecnie, po dziesięciu latach wygląda dobrze (ryc. 3), prawie tak jak po wykonaniu w 1994 roku. Zmieniony został kolor obramień okiennych na ciemny ugier, w myśl sugestii Marii Strzałko, ówczesnej Miejskiej Konserwator Zabytków, co spowodowało większą wyrazistość dekoracji malarskiej.

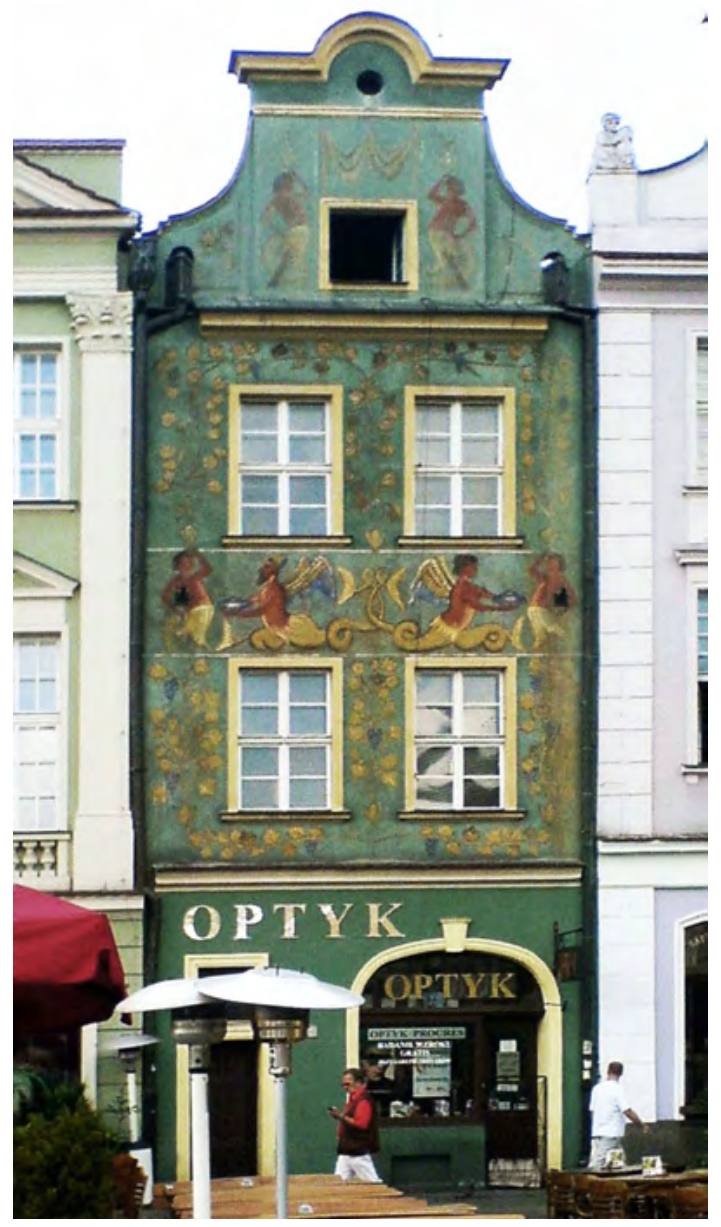

Ryc. 1. Kamienica na Starym Rynku 66, przed konserwacją i restauracją, fresk, 1994 r., fotografia przed 2010 r.

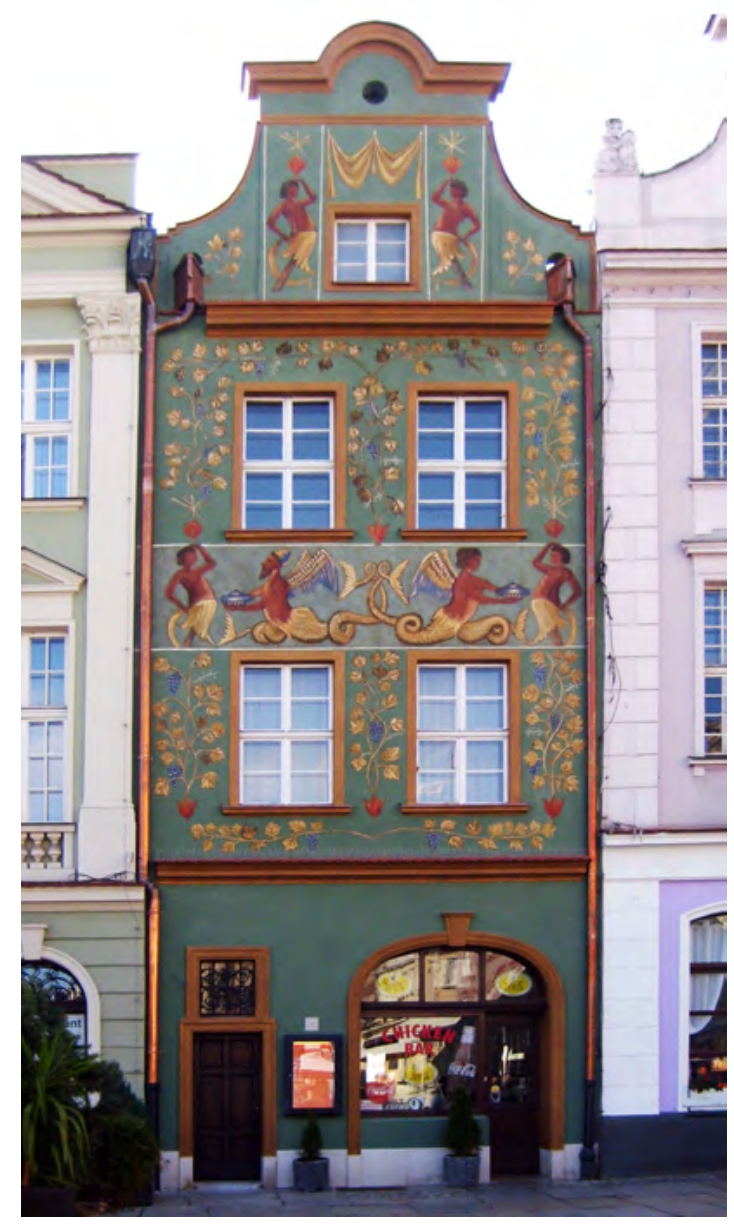

Ryc. 2. Kamienica na Starym Rynku 66 po wymianie rynien i konserwacji i restauracji polichromii w 2010 r.

\section{Doświadczenia z innymi kamienicami}

W 1997 ówczesny Miejski Konserwator Zabytków Witold Gałka zaproponował zaprojektowanie i wykonanie kolejnej dekoracji malarskiej na kamienicy przy ul. Paderewskiego 3, niedaleko Starego Rynku.

Kamienica ta była odbudowana w formach pseudobarokowych, na siedzibę, nieistniejącego już, Pomorskiego Banku Kredytowego. Obecnie znajduje się tam siedziba Oddziału Banku PKO SA w Poznaniu. Budynek postawiono częściowo na pozostałościach starszej budowli ${ }^{14}$. 
Na elewacji kamienicy przy ul. Paderewskiego 3 nie było w przeszłości dekoracji malarskiej, powstał zupełnie nowy projekt. Zaprojektowano bogatą dekorację malarską, sięgając do ikonografii z arrasów wawelskich. Pojawiły się tam fantazyjne zwierzęta, a całość elewacji była pokryta dekoracyjnymi elementami. Zleceniodawca nie chciał się zgodzić na rozbudowaną polichromię i w rezultacie powstała bardziej oszczędna, delikatna kompozycja. Znajduje się na niej wić roślinna, róg obfitości, dwie niebieskie wazy oraz w kilku miejscach na elewacji, przewijają się dekoracyjne wstęgi.

Uwarunkowania techniczne wynikające z użycia farb silikatowych, spowodowały, że cała kompozycja ma bardziej graficzny charakter, niż to ma miejsce na wykonanej w technice fresku, elewacji kamienicy na Starym Rynku 66. Technika wykonania była uwarunkowana tym, że elewacja została przygotowana w technice silikatowej. Do malowania dekoracji malarskiej użyto także farb silikatowych. Nie wszystkie kolory farb silikatowych udało się zdobyć i stąd w śladowej ilości odstąpiono od czystości technologicznej fragmentów malatury, używając pigmentu ze spoiwem akrylowym, przeznaczonym do malarstwa ściennego, co zupełnie nie wpłynęło na ich trwałość. Obecnie po 24 latach sama dekoracja wygląda dobrze, jest to wynikiem techniki silikatowej i systemu odprowadzania wody z dachu budynku, rynny nie przechodzą przez elewację. Pewne zmiany nastąpiły w samym tle, czyli w warstwie położonej pod malaturą. Natomiast sama dekoracja malarska wykazuje znacznie większą trwałość niż w przypadku mokrego fresku (ryc. 4).

W latach 1985-1986, w czasie kiedy prezydentem Poznania był Andrzej Wituski, przeprowadzono rewaloryzację polichromii kamienic na Starym Rynku, w Poznaniu pod nadzorem Zbigniewa Bednarowicza oraz przy udziale artystów plastyków, którzy opracowali pod względem plastycznym, poszczególne elewacje w okresie odbudowy ${ }^{15}$.

Właśnie podczas tej rewaloryzacji doszło do odtworzenia w 1986 roku wraz z artystą Pawłem Łubowskim ${ }^{16}$ fresku z 1955 roku, autorstwa Edmunda Łubowskiego, na elewacji kamienicy na Starym Rynku $39^{17}$ oraz sgraffita autorstwa Józefa Fliegera na kamienicy $\mathrm{nr} 99^{18}$ z 1960 roku. Pierwsza z tych kamienic była odtwarzana po konturze zachowanej malatury, a druga była odtwarzana od początku poprzez nakładanie trzech warstw barwionej zaprawy i jej cięcia według na nowo rozrysowanego kartonu.

\section{Problemy estetyczne i techniczne}

Wystrój plastyczny na Starym Rynku w Poznaniu wykonany po II Wojnie Światowej był realizowany według wytycznych architektów i urbanistów z zespołu kierowanego przez Zbigniewa Zielińskiego wyrażonych takimi słowami: ...Rekonstrukcja w stylu poszczególnych epok nie może tutaj mieć miejsca z braku jakiejkolwiek dokumentacji i śladów dawnej polichromii. Malując Stary Rynek, należy sięgnać nie tylko do dawnych poznańskich motywów i wzorów, ale przede wszystkim należy się starać, aby dekoracja malarska odpowiadała wymogom wspótczesnej nam sztuki i aby kolorystycznie stała na najwyższym poziomie, do jakiego doszła sztuka wspótczesna. Przyszłe pokolenia musza mieć petna świadomość, że ogląają na fasadach kamieniczek malowidła z roku 1955, że widza powodu sztukę z połowy XX wieku, zharmonizowana z elementami poznańskiego renesansu, baroku i klasycyzmu ${ }^{19}$.

15 I. Błaszczyk, Stary Rynek, Sprawozdania konserwatorskie z prac w latach 1945-2016, część 2, w: I. Błaszczyk (red), Stare Miasto w Poznaniu. Zniszczenia Odbudowa Konserwacja 1945-2016 Wydawnictwo Miejskie Posnania, Poznań 2017, s. 168-169.

16 Paweł Łubowski to brat autora Andrzeja Macieja Łubowskiego.

17 H. Kondziela, Stary Rynek, Kamienica Stary Rynek 39, Sprawozdania konserwatorskie z prac w latach 1945-2016, część 2, w: I. Błaszczyk (red), Stare Miasto w Poznaniu. Zniszczenia Odbudowa Konserwacja 1945-2016, Wydawnictwo Miejskie Posnania, Poznań 2017, s. 186.

18 H. Kondziela, Stary Rynek, Kamienica Stary Rynek 97/100, Sprawozdania konserwatorskie z prac w latach 1945-2016, część 2, w: I. Błaszczyk (red), Stare Miasto w Poznaniu. Zniszczenia Odbudowa Konserwacja 1945-2016, Wydawnictwo Miejskie Posnania, Poznań 2017, s. 225.

19 M. Brzeziński, Powojenna Odbudowa Starego Rynku, https://www.miastopoznaj.pl/blogi/pozostale/2066-powojenna-odbudowa-staregorynku, Poznań 2015. 


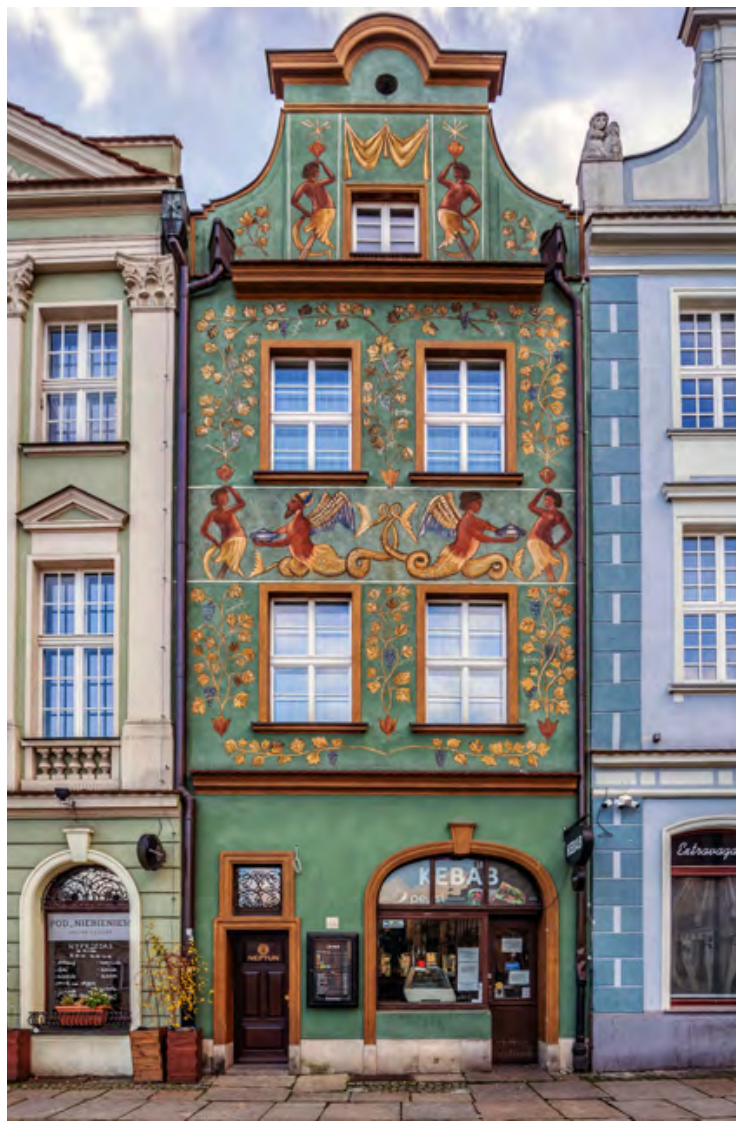

Ryc. 3. Kamienica na Starym Rynku 66, fresk. Stan obecny 10 lat po konserwacji i restauracji, fot. Krzysztof Ślachciak, 2020 r.

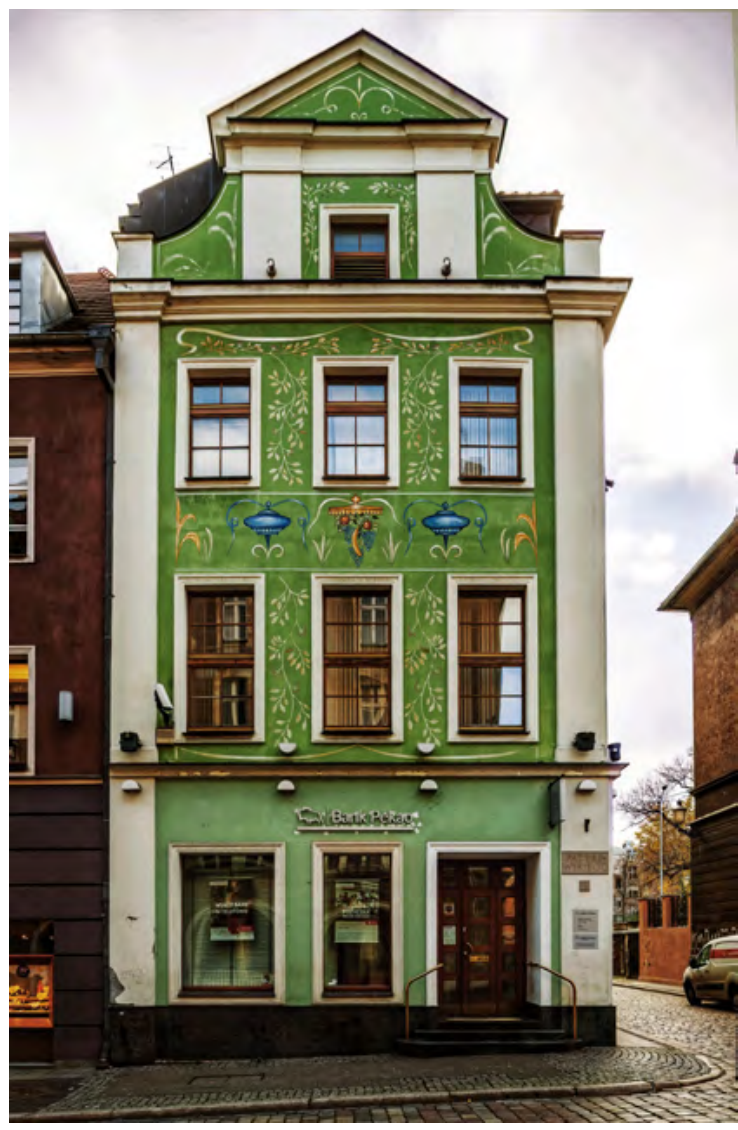

Ryc. 4. Polichromia kamienicy przy ul. Paderewskiego 3, silikat, 1997 r., fot. Krzysztof Ślachciak, 2020 r.

Sposób odbudowy Starego Miasta w Poznaniu i w innych miastach Polski po II Wojnie Światowej został ukierunkowany względami emocjonalnymi i tożsamościowymi, wbrew wykładni sformułowanej na początku XX wieku przez austriackiego historyka sztuki Aloisa Riegla dotyczącej konserwacji zabytków. Uważał on, że konserwacja powinna dotyczyć tylko zachowanej materii zabytkowej wraz z nawarstwieniami, był to głos opowiadający się za autentyzmem. Do dzisiaj toczą się spory w tej kwestii, w przypadkach odbudowy kompletnie zniszczonych zabytkowych budynków ${ }^{20}$. Odmienną drogą, wytyczoną przez odbudowę Starego Miasta w Warszawie, za którą stała myśl ówczesnego generalnego konserwatora zabytków prof. Jana Zachwatowicza, podążyły inne miasta Polski ${ }^{21}$. Trzeba jednak stwierdzić, że odbudowa Starego Miasta w Warszawie stworzyła dzieło sztuki, będące dokumentem epoki, podlegającym ochronie konserwatorskiej i które w 1980 r. zostało wpisane na listę światowego dziedzictwa kulturowego UNESCO.

Odbudowany Stary Rynek w Poznaniu także stał się dokumentem powojennych czasów i powstałe w tamtym czasie realizacje plastyczne stają się zabytkami.

Warunki wynikające z klimatu i problemów technicznych powodują, że wystrój plastyczny kamienic ulega degradacji i istnieje stała potrzeba działań naprawczych. Przyczyną są często niedrożne rynny, ściekająca woda zmywa freski i destruuje tynki. Szczególnie narażone są też szczyty kamienic, gdzie na skutek większego wystawienia na opady atmosferyczne zanikają znajdujące się tam malatury. 


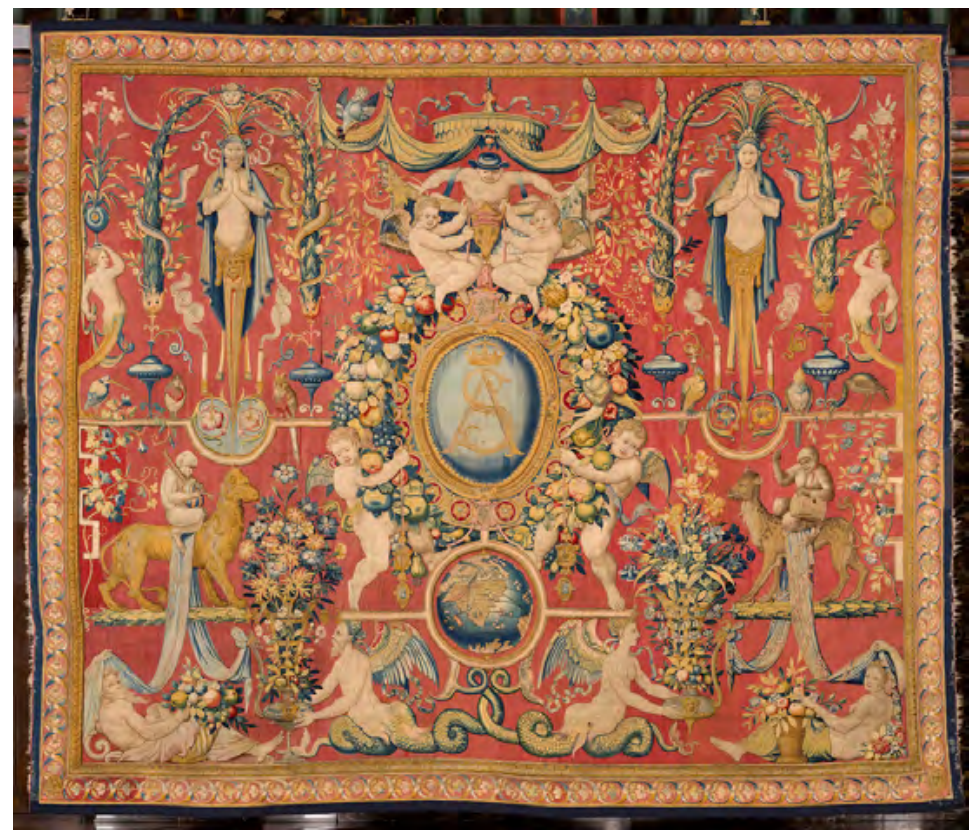

Ryc. 5. Z kręgu Cornelisa Florisa i Cornelisa Bosa, warsztat Fransa Ghieteelsa?, Arras z monogramem Zygmunta Augusta, $287 \times 410 \mathrm{~cm}$, wełna, jedwab, nić srebrna, nić złota, Bruksela, Flandria, Zamek Królewski na Wawelu Państwowe Zbiory Sztuki, ok. 1555 r.

Przedstawione działania naprawcze wymienione powyżej, udokumentowane w literaturze na podstawie sprawozdań konserwatorskich nakłaniają do ich zestawienia w tabelach.

Tabela 1. Działania naprawcze

\begin{tabular}{|l|ccccc|}
\hline $\begin{array}{c}\text { Lokalizacja } \\
\text { kamienicy }\end{array}$ & Technika & Rok powstania & $\begin{array}{c}\text { Rok } \\
\text { odtworzenia }\end{array}$ & $\begin{array}{c}\text { Rok konserwacji } \\
\text { i restauracji }\end{array}$ & $\begin{array}{c}\text { Stan zachowania } \\
\mathbf{2 0 2 1} \text { r. }\end{array}$ \\
\hline Stary Rynek 99 & sgraffito & 1960 & 1985 & - & zły \\
\hline Stary Rynek 39 & mokry fresk & 1956 & 1986 & 2011 & dobry \\
\hline Stary Rynek 66 & mokry fresk & 1994 & - & 2010 & dobry \\
\hline Paderewskiego 3 & farby silikatowe & 1997 & - & - & dobry \\
\hline
\end{tabular}

Tabela 2. Przedziały czasowe pomiędzy działaniami naprawczymi

\begin{tabular}{ccc} 
Lp. & Kamienica & Przedział czasowy \\
\hline 1. & $\begin{array}{c}\text { Kamienica przy Starym Rynku } 99 \\
\text { (sgraffito) }\end{array}$ & $\begin{array}{c}\text { od powstania do otworzenia }-25 \text { lat, } \\
\text { od otworzenia do chwili obecnej }-36 \text { lat }\end{array}$ \\
\hline 2. & $\begin{array}{c}\text { Kamienica na Starym Rynku } 39 \\
\text { (mokry fresk) }\end{array}$ & $\begin{array}{c}\text { od powstania do otworzenia }-30 \text { lat, } \\
\text { od odtworzenia do konserwacji i restauracji }-25 \text { lat }\end{array}$ \\
3. & $\begin{array}{c}\text { Kamienica przy Starym Rynku } 66 \\
\text { (mokry fresk) }\end{array}$ & od powstania do konserwacji i restauracji - 16 lat \\
4. & $\begin{array}{c}\text { Kamienica przy ul. Paderewskiego } 3 \\
\text { (farby silikatowe) }\end{array}$ & $\begin{array}{c}\text { od powstania do chwili obecnej (2021 r.) } \\
\text { jest w dobrym stanie }-24 \text { lata }\end{array}$
\end{tabular}


Tabela 3. Zestaw czynników wpływających na stan polichromii

\author{
Podstawowe czynniki wpływające na stan zachowania polichromii \\ 1. Technika wykonania \\ 2. Błędy technologiczne \\ 3. Warunki atmosferyczne
}

4. Zanieczyszczenie środowiska

5. Wadliwy system odprowadzenia wody z dachu

Okazuje się, że polichromie kamienic przy Starym Rynku 66 (1994) i Paderewskiego 3 (1997) wykonane od nowa w różnych technikach wykazują inną trwałość. Polichromia na kamienicy przy Starym Rynku 66 wykonana w technice mokrego fresku po 16 latach musiała być poddana konserwacji i restauracji, a dekoracja malarska na kamienicy przy ul. Paderewskiego 3, wykonana w technice krzemianowej (silikat), po upływie 24 lat jest w dobrym stanie.

W latach 2010-2012 elewacje kamienic przy Starym Rynku 39 i 66 były odnawiane i przy okazji dekoracje malarskie były poddane konserwacji i restauracji przez osoby z uprawnieniami konserwatorskimi.

Sgraffito na kamienicy 99 nie było konserwowane i restaurowane w 2012 r. przy okazji odnowienia sąsiednich elewacji i jest w złym stanie, nie wiadomo czy dekorację malarską da się uratować. Natomiast dokonana w 2012 r. w jej pobliżu na kamienicy 97 konserwacja i restauracja dekoracji wykonanej w technice sgraffita spowodowała, że polichromia na niej jest obecnie w dobrym stanie zachowania.

Stan zachowania w 2021 r. wszystkich wymienionych polichromii autor artykułu stwierdził osobiście po przeglądzie elewacji poszczególnych kamienic.

\title{
Krótka charakterystyka użytych technik malarskich
}

Na zewnątrz budynków w celu zachowania trwałości polichromii budynków stosuje się spoiwa mineralne.

W wyżej wymienionych realizacjach dekoracji malarskich zastosowane zostały następujące techniki: technika mokrego fresku, technika krzemianowa (silikat) oraz technika sgraffita.

Technika fresku mokrego ${ }^{22}$, zastosowana przy polichromiach kamienic przy Starym Rynku 66 i 39, jest znana od dawna, naukowcy wywodzą ją od malarstwa jaskiniowego, w XV wieku zyskała powszechne uznanie i miano królowej technik malarskich. Szczególnie przyjęła się we Włoszech. Spoiwem w tej technice jest świeża zaprawa wapienna otrzymana z wapna gaszonego ( wodorotlenek wapnia) i piasku. Wapno gaszone otrzymuję się $z$ wapna palonego (tlenek wapniowy) zmieszanego z wodą według reakcji $\mathrm{CaO}+\mathrm{H}_{2} \mathrm{O}=\mathrm{Ca}(\mathrm{OH})_{2}$ i następnie dołowanego. Fresk wykonuje się na mokrym podłożu w systemie dniówkowym. Barwniki pochodzenia mineralnego odporne na alkaliczne działanie wapna, rozcieńczane w wodzie, wodzie wapiennej lub wodzie barytowej uzyskują spoiwo ze świeżej zaprawy, gdzie wapno gaszone pod wpływem dwutlenku węgla z powietrza przemienia się w krystaliczny węglan wapnia, która twardniejąc czyni je wodoodpornymi. To wiązanie ściśle łączy malowidło z zaprawą w warstwę krzemianu wapniowego. Trwałość fresk mokry zawdzięcza reakcji chemicznej i trwałości zaprawy. Na fresk mokry szkodliwie działają: zanieczyszczenia atmosferyczne( kwas węglowy i kwas siarkowy, wahania temperatury, oraz owady.

Technika krzemianowa ${ }^{23}$ jest stosunkowo młoda, decydujące było poszukiwanie techniki przypominającej mokry fresk, odpornej na warunki atmosferyczne, zalecone przez króla Ludwika II Bawarskiego (1864-1886), ponieważ mokry fresk nie sprawdzał się w Bawarii. Szereg naukowców poczyniło poszukiwania w tej kwestii, jednak to Adolf Wilhelm Keim w 1878 roku opatentował wynalezione przez siebie farby krzemianowe z użyciem szkła wodnego i barwników mineralnych. Spoiwem jest szkło wodne, bezbarwna ciecz rozcieńczalna w wodzie, 
połączenie krzemu z sodem lub potasem. Są to krzemian sodu $\left[\mathrm{Na}_{2} \mathrm{O}_{n} \mathrm{Si}_{2}(\mathrm{n}=3-5)\right]$, krzemian potasu $\left(\mathrm{K}_{2} \mathrm{SiO}_{3}\right)$ oraz podwójne szkło wodne - mieszanina potasowego i sodowego szkła wodnego. Farby Keima wymagają w zaprawie dodatku cementu, farby wnikają w zaprawę i łączą się z jej składnikami kamieniejąc tworzą krzemienną skałę, nie tworzą one szczelnej błony, pory zaprawy nie zostają zamknięte przy wymianie wilgotności i powietrza co wpływa na trwałość polichromii. Farby Keima po zaschnięciu i chemicznej reakcji są odporne na wodę, trwałe zmiany atmosferyczne. Tworzą powłoki odporne na chemikalia( kwasy i ługi), rozpuszczalniki przemysłowe i spaliny, nie stanowią pożywki dla mikroorganizmów.

Farby silikatowe, zastosowane przy polichromii kamienicy przy ul. Paderewskiego 3, są odmianą farb krzemowych, jednokomponentową mieszaniną barwnika ze środkiem wiążącym, można je nabyć gotowe, są rozcieńczalne w wodzie i maluje się nimi na suchym podłożu.

W technice sgraffita ${ }^{24}$ używa się podobnych zapraw i spoiwa jak w fresku mokrym, stosuje się zaprawę wapienną. Sgraffito nie jest dosłownie malarstwem, ale techniką dekoracyjną w której rysunek odgrywa decydującą rolę. Można powiedzieć, że jest to technika rysunkowa w wilgotnej zaprawie mineralnej. Porównuje się ją do drzeworytu, tylko w drzeworycie wypukłe linie i płaszczyzny są rysunkiem, a w sgrafficie wklęsłe powstałe z wydrapania pobiały lub wycięcia wilgotnej zaprawy. Sgraffito może być dwubarwne lub wielobarwna, sgraffito dwubarwne tworzy się przez sporządzenie narzutu wyrównawczego, położenie warstwy zaprawy barwionej i na niej pobiały wapiennej lub zaprawy bezbarwnej, a następnie wydrapuje się lub wycina rysunek odsłaniając spodnią warstwę. Sgraffito wielobarwne, zastosowane w polichromii kamienicy przy Starym Rynku 99, powstaje poprzez wycinanie w kilku warstwach nałożonej, wilgotnej, barwionej zaprawy. Pracuje się podobnie jak wykonując mokry fresk w systemie dniówkowym, pracując tylko na wilgotnej zaprawie. Na trwałość sgraffita wpływa stan podobrazia czyli muru ceglanego lub kamiennego. Szkodliwy wpływ mają także podobne czynniki jak przy mokrym fresku.

\section{Wnioski}

Zamiarem autora artykułu było zbadanie wpływu czasu i techniki wykonania na stan zachowania polichromii kamienic w tym konkretnym miejscu, na Starym Rynku w Poznaniu na podstawie prześledzenia trwałości polichromii na elewacjach kilku kamienic, z którymi autor był bezpośrednio związany poprzez projektowanie, wykonawstwo oraz działania naprawcze.

Po analizie przedziałów czasowych pomiędzy latami wykonania, a interwencjami naprawczymi i zaznajomieniu się z właściwościami użytych spoiw mineralnych: wapiennych fresku mokrego i sgraffita oraz krzemianowych (silikat) nasuwają się następujące wnioski.

1. Zastosowanie techniki fresku mokrego jest problematyczne i z powodu braku odporności na warunki atmosferyczne i zanieczyszczenie środowiska związanego z rozwojem współczesnej cywilizacji.

2. Zastosowanie techniki sgraffita z powodu użycia spoiwa wapiennego daje podobne do fresku mokrego słabe gwarancje trwałości i utrzymania dobrego stanu zachowania.

3. Zastosowanie techniki krzemianowej daje o wiele większe gwarancje utrzymania dobrego stanu zachowania z powodu swoich właściwości dające odporność na trwałe zmiany atmosferyczne, powstającej powłoki odpornej na chemikalia (kwasy i ługi), rozpuszczalniki przemysłowe i spaliny.

4. W odpowiednim czasie przeprowadzone konserwacje i restauracje polichromii znacznie przedłużają dobry stan ich zachowania. Dotyczy to szczególnie technik fresku mokrego i sgraffita.

Powstanie polichromii kamienic na Starym Rynku w Poznaniu uwarunkowane było specyficznymi wydarzeniami związanych z odbudową po zniszczeniach wojennych. W rezultacie powstały obiekty architektoniczne, które są krytykowane pod względem autentyczności, ale z powodu kryterium czasowego stają się zabytkami ${ }^{25}$, są one dokumentami epoki, w której powstawały i powinny być jak najlepiej zachowane zarówno w zakresie architektury jak i polichromii. 


\section{Literatura}

[1] Błaszczyk I. (red), Stare Miasto, w Poznaniu. Zniszczenia-Odbudowa - Konserwacja 1945-2016, Wydawnictwo Miejskie Posnania, Poznań 2017.

[2] Zwolińska K., Mała technologia Malarstwa, Wydawnictwa Centralnego Ośrodka Metodyki Upowszechniania Kultury, Warszawa 1989.

[3] Kondziela H., Miasto Poznań (1955-1957), Ochrona Zabytków 12/1 (44), 72-76, https://docplayer.pl/amp/17688207-H-kondziela-miasto-poznan-1955-1957-ochrona-zabytkow-12-1-44-72-76.html.

[4] Topolski J. (red), Dzieje Poznania, tom I, Państwowe Wydawnictwo Naukowe, Warszawa-Poznań 1988.

[5] Przybek P., Materiaty Malarskie, Wydawnictwo 400 d\&, Kraków 2004.

[6] Ślesiński W., Techniki Malarskie. Spoiwa mineralne, Wydawnictwo Arkady, Warszawa 1983.

[7] Kostyrko T. (red), Sztuki plastyczne w Poznaniu 1945-1980, Wydawnictwo Poznańskie, Poznań 1987.

[8] Warkoczewska M. (red), W cieniu ratuszowej wieży Kronika Miasta Poznania, 2003/2, Poznań 2003.

[9] Zachwatowicz J., Ochrona zabytków w Polsce, Wydawnictwo Polonia, Warszawa 1965.

[10] Kasprowicz R., Alois Riegl, Georg Dehio i kult zabytków, Oficyna Wydawnicza "Mówią Wieki", Warszawa 2006.

\section{Retrospection: genesis and durability of post-war polychromes of tenement houses in the Old Market Square in Poznań}

Abstract: The article presents the artist's and researcher's own artistic experiences related to the implementation of painting decorations of tenement houses at the Old Market Square in Poznań. These are the works created in 1986, 1994 and 1997.

The first project was a consequence of quite unexpected incorporation of the polychrome of the tenement houses at the Old Market Square in Poznań. It was about 30 years, after World War II, when the polychrome on the reconstructed tenement houses was created. There was a need to restore the painting decorations by Edmund Łubowski on a tenement house at 39 Stary Rynek and the sgraffito by Józef Flieger at 99 Stary Rynek. The situation was a consequence of such advanced destruction that it was impossible to renew the works. Due to the fact that the authors were then still alive, it was possible to consult the reconstruction process.

In 1994, the author received another proposal to make, according to his own design, a new painting decoration, made in the wet fresco technique, on a tenement house at 66 Stary Rynek. Later, in 2010, the restoration and conservation work was conducted in consultation with the author.

In 1997, a painting decoration was designed on the tenement house at 3 Paderewskiego Street, close to the urban interior of the Old Market Square. Based on the project, painting decorations were made in the silicate technique.

The artist's experience, drawn from the aforementioned works, has become the subject of qualitative research that correlates the passage of time and the type of wall painting techniques used as well as other technical conditions influencing the state of preservation of the polychrome with artistic issues.

Keywords: architecture, reconstruction, polychromy, Old Market Square in Poznań, mineral binders, state of preservation, conservation, restoration 